\title{
Review
}

\section{Higenamine in Plants as a Source of Unintentional Doping}

\author{
Vanya Rangelov Kozhuharov*, Kalin Ivanov and Stanislava Ivanova
}

check for updates

Citation: Rangelov Kozhuharov, V.; Ivanov, K.; Ivanova, S. Higenamine in Plants as a Source of Unintentional Doping. Plants 2022, 11, 354. https:// doi.org/10.3390/plants11030354

Academic Editor: Filippo Maggi

Received: 12 January 2022

Accepted: 26 January 2022

Published: 27 January 2022

Publisher's Note: MDPI stays neutral with regard to jurisdictional claims in published maps and institutional affiliations.

Copyright: (C) 2022 by the authors. Licensee MDPI, Basel, Switzerland. This article is an open access article distributed under the terms and conditions of the Creative Commons Attribution (CC BY) license (https:// creativecommons.org/licenses/by/ $4.0 /)$.
Department of Pharmacognosy and Pharmaceutical Chemistry, Faculty of Pharmacy, Medical University-Plovdiv, 4002 Plovdiv, Bulgaria; kalin.ivanov@mu-plovdiv.bg (K.I.); stanislava.ivanova@mu-plovdiv.bg (S.I.)

* Correspondence: vanya.kozhuharov@mu-plovdiv.bg

\begin{abstract}
Background: Higenamine is a $\beta_{2}$ agonist of plant origin. The compound has been included in WADA's prohibited list since 2017. Higenamine may be detected in different plants and many food supplements of natural origin. Methods: Our literature search was conducted through PubMed, Science Direct, Google Scholar, and Web of Science studies investigating the presence of higenamine in plants that are used in traditional folk medicine or included in food supplements. Our study aimed to assess the risk of adverse analytical findings caused by higenamine-containing plants. Results: Based on our literature search, Nelumbo nucifera, Tinospora crispa, Nandina domestica, Gnetum parvifolium, Asarum siebodii, Asarum heterotropoides, Aconitum carmichaelii, and Aristolochiabrasiliensis are higenamine-containing plants. Based on data from Eastern folk medicine, these plants can provide numerous health benefits. Professional athletes likely ingest these plants without knowing that they contain higenamine; these herbs are used in treatments for different conditions and various foods/food supplements in addition to folk medicine. Conclusion: Athletes and their teams must be aware of the issues associated with the use of plant-based products. They should avoid consuming higenamine-containing plants during and outside of competition periods.
\end{abstract}

Keywords: higenamine in plants; Nelumbo nucifera; Tinospora crispa; Nandina domestica; Gnetum parvifolium; Asarum siebodii; Aconitum carmichaelii; Aristolochia brasiliensis

\section{Introduction}

Plant species are one of the most significant sources for current drug discovery [1]. Many important medicines have plant origins, and there are still thousands of unexplored molecules that have obtained from plants. Nowadays, many plant extracts are included in food supplements. The use of these extracts are often based on data available from folk medicine.

The use of herbal supplements by athletes increased in the last 10 years [2]. Herbal food supplements include extracts from seeds, roots, leaves, berries, or whole plants. These extracts generally contain many phytochemicals, such as polyphenols, carotenoids, alkaloids, flavonoids, glycosides, saponins, lignans, etc., which can potentially enhance athletes' performance or recovery [3,4].

Athletes' complex supplementation is an important part of their nutritional regimes. At the same time, food supplements may be a source of unintentional doping (Figure 1). Many studies have reported on undeclared compounds found in different food supplements (FS) [5-16]. The main reasons for the unintentional intake of doping compounds are:

1. Undeclared doping compounds in commercial products are naturally present in the phytochemical composition of plant extracts (e.g., higenamine, ephedrine, synephrine, and morphine).

2. Contaminated food supplements with doping compounds (e.g., anabolic agents, sibutramine, clenbuterol).

3. Insufficient educational programs for doping prevention. 
Mild regulation for food supplements and fast introduction on the market
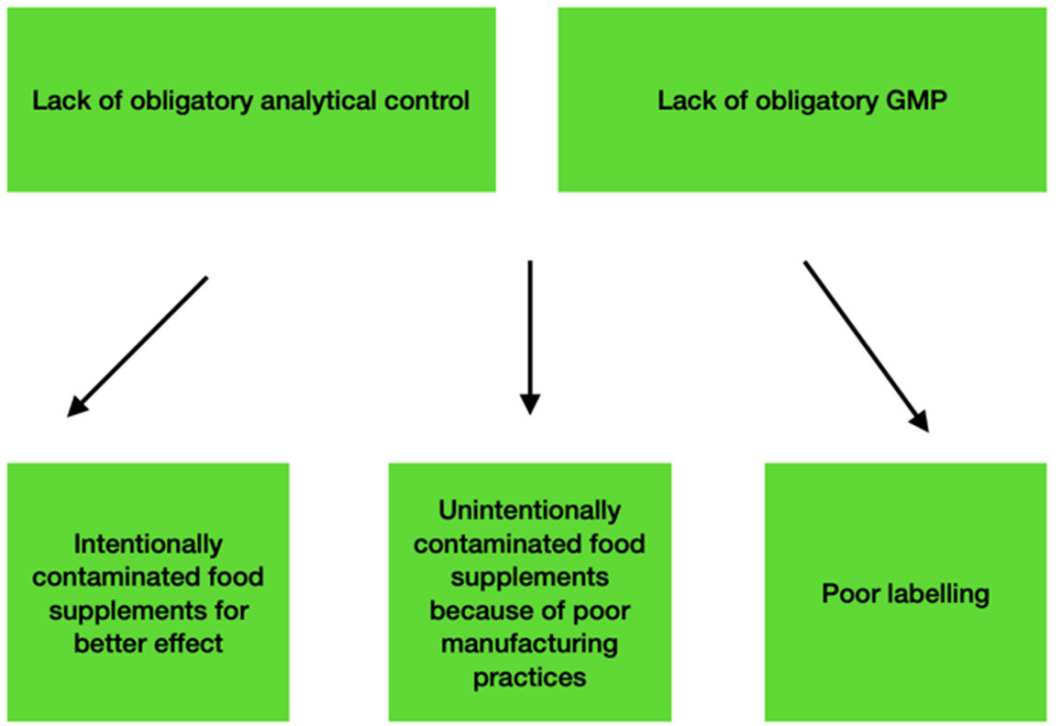

Figure 1. Food supplements as a source of unintentional doping.

The intake of such products exposes athletes to risk. Usually, FS-containing, undeclared compounds are the result of poor manufacturing practices, and it is difficult to avoid because the majority are labeled as vitamins, minerals, proteins, or other non-prescription products. However, some plant extracts should be avoided to prevent the unintentional intake of doping compounds by food supplements. Most of these extracts are used as stimulants. A good example is methylhexaneamine (Geranamine), a stimulant included in the World Anti-Doping Agency's (WADA) prohibited list, which may be found in the Geranium and Pelargonium species known collectively as Geraniaceae [17]. According to WADA, there have been several examples of athletes testing positive for methylhexaneamine in recent years, notably during the Olympic Games. WADA warns that the term "methylhexaneamine" is rarely seen on dietary supplement labels, and this stimulant is often known as geranium root extract or geranium oil [18]. Professional athletes should avoid food supplements labeled as geranium root extract or geranium oil.

Higenamine (1-[(4-hydroxyphenyl) methyl]-1,2,3,4-tetrahydroisoquinoline-6,7-diol is a benzyltetrahydroisoquinoline alkaloid whose structure is similar to epinephrine and norepinephrine (Figure 2). The compound is a natural agonist of $\beta$-adrenoreceptors.<smiles>Oc1ccc(CC2NCCc3cc(O)c(O)cc32)cc1</smiles>

Higenamine<smiles>NC[C@@H](O)c1ccc(O)c(O)c1</smiles>

Epinephrine<smiles>CNC[C@H](O)c1ccc(O)c(O)c1</smiles>

Norepinephrine<smiles>Oc1ccccc1O</smiles>

Catechol

Figure 2. Higenamine, epinephrine, norepinephrine, and catechol structures.

Despite the similarities between these structures, there are some important differences: epinephrine and norepinephrine are classical examples of catecholamines (Figure 2), 
whereas higenamine consists of a catechol ring attached to a piperidine ring joined to a p-hydroxybenzyl group.

Higenamine has an asymmetric carbon $(\mathrm{C}-1)$ in its structure and can exist in two conformations, S-(-)- higenamine and $R-(+)-$ higenamine (Figure 3) [19-22]. S-(-)higenamine is an important biosynthetic precursor in the biosynthesis of benzylisoquinoline alkaloids in plants [19].<smiles>Oc1ccc(C[C@@H]2NCCc3cc(O)c(O)cc32)cc1</smiles>

(R)-(+)- higenamine<smiles>Oc1ccc(C[C@@H]2NCCc3cc(O)c(O)cc32)cc1</smiles>

(S)-(-)- higenamine

Figure 3. $S$-(-)-higenamine and $R-(+)$-higenamine structures.

The biosynthetic pathway that leads to $S$-(-)-higenamine originates from Pictet-Spengler condensation of dopamine and 4-hydroxyphenylacetaldehyde (4-HPAA) by norcoclaurine synthase $[20,21]$. Although it is expected for norcoclaurine synthase to produce only tetrahydroisoquinolines with $S$ - stereochemistry [22], higenamine was isolated in a racemic form or as $R-(+)$-higenamine from several plants [23-25].

There are several differences between the biological activity of the two enantiomers. According to recent studies, $S$-(-)-higenamine demonstrates stronger cardiotonic properties and anti-platelet effects than $R-(+)$-higenamine $[24,26]$. It was also reported that $S-(-)-$ higenamine shows better effects in disease that are associated with inducible nitric oxide synthase over-expression [27]. These important differences in their bioactivities lead to the development of enantioselective methods for the synthesis of the two enantiomers [22,26].

For the first time the compound was isolated from aconite roots (Aconitum japonicum; Ranunculaceae) by Kosuge in 1976 [24] and identified as Aconitum's active cardiotonic compound. In Chinese and Japanese folk medicine, Aconitum japonicum has an important role. Its extracts are keenly used to treat fever, collapse, pain, gastroenteritis, diarrhea, edema, bronchial asthma, and various tumors [28].

In Europe and North America, higenamine is a common ingredient in dietary supplements and is used for its anti-obesity and performance-enhancing effects [29]. A study from the Netherlands reported that between 2013 and 2018, 28 of 416 supplements analyzed contained higenamine. Data suggest that higenamine ranks fifth after caffeine, synephrine, sildenafil, and icariin as an adulterant in dietary supplements [30].

Due to its structural similarities to epinephrine, higenamine interacts with $\beta_{2}$ adrenoreceptors and increases cardiac output and heart rate. Feng et al.'s study showed that the heart rate accelerated within $2 \mathrm{~min}$ of administering higenamine [31]. Higenamine has a short half-life-about $8.0 \mathrm{~min}$ - and is quickly eliminated from the body. According to their findings, only $9.3 \%$ was removed by renal excretion, whereas the liver played a larger role in its elimination. A total of $94 \%$ of the compound is eliminated from the human body after $30 \mathrm{~min}[31]$.

Various studies conducted over time have described the positive inotropic and chronotropic effects of higenamine (agonist of $b 1$ and b2 adrenergic receptors) [31-35]. Higenamine also has a hypotensive effect, correlated with its antagonist effect to $\alpha_{1}$-adrenergic receptors [36]. It also inhibits the signaling pathways of TGF-b1/Smad and plays a role in preventing fibrosis and cardiac hypertrophy [37]. The anti-inflammatory effects of higenamine are due to its suppression of interleukin-1 $\beta$ [38]. Investigations have also reported antioxidant activity by the reduction of reactive oxygen species and induction of heme oxygenase$1[39,40]$. The intake of higenamine is associated with enhanced glucose uptake and 
glucose metabolism, relaxation of the trachea and colon, and anti-thrombotic effects [41-43]. According to its mechanism of action, higenamine can be used for treating heart failure, erectile dysfunction, bradyarrhythmia, and arthritis [1].

Since 2017, higenamine has been included in the World Anti-Doping Agency's (WADA) Prohibited List because of its $\beta_{2}$-adrenergic properties [44]. Although the compound has demonstrated beneficial therapeutic effects on different disorders [1], no medicines currently contain higenamine. At the same time, athletes might unintentionally ingest higenamine because it is present in the phytochemical composition of many herbs included in food supplements.

Higenamine can be found in a wide range of commercially available supplements; however, the labeling of such items may not indicate its existence or appropriately describe the amount contained. Cohen et al. discovered higenamine in 24 easily accessible supplements, most of which advertised weight loss and energy enhancement. The researchers reported that higenamine concentrations in these products were $62 \pm 6.0 \mathrm{mg}$ per serving [45]. Higenamine consumption can increase blood pressure and cause an irregular heartbeat $[29,31]$. Intravenous administration of higenamine at the dose of $22.5 \mu \mathrm{g} / \mathrm{kg}$ was shown to have a good degree of safety [31]. Minor and short-term adverse effects after the intake of $22.5 \mu \mathrm{g} / \mathrm{kg}$ of higenamine, such as dizziness, chest congestion, heart palpitations, chest congestion, and dry mouth, have been reported in human clinical studies [46,47]. A study of 48 healthy men reported that peroral higenamine intake for eight weeks did not significantly change heart rate, blood pressure, blood lipids, or liver enzyme activity [47]. However, higenamine's toxicity is related mostly with the cardiovascular systems by enhancing aconitine-induced tachyarrhythmia and myocardial contractility [32].

Jeter et al. reported the case of a 22-year-old with paraspinal muscle rhabdomyolysis associated with the use of dietary supplements containing higenamine, but the quantity of higenamine was not declared [48].

WADA set criteria for higenamine as a prohibited substance, stating that analytical findings should not be reported at levels under $10.0 \mathrm{ng} / \mathrm{mL}$ [49]. Appropriate methods for detecting and quantifying higenamine in dietary supplements and biological samples have been developed to minimize the misuse of higenamine, including LC-MS/MS, UHPLCMS/MS, and GC-MS combined with derivatization [50-54].

In a 2020 report from WADA, anti-doping testing figures show that higenamine use is increasing and that higenamine ranked second as a $\beta 2$ agonist. Higenamine had adverse analytical findings in 26 cases [55]. The USADA (United States Anti-Doping Agency) reported different sanctions ranging from 10 to 20 months for athletes that violated antidoping rules by testing positive for higenamine. Investigations attributed positive samples to the use of dietary supplements [56-58].

Although higenamine is a doping agent found in many plants and food supplements, data about higenamine in the English language are limited. Data concerning sources of higenamine and its pharmacological activity should be included in educational programs for doping prevention.

Our study aims to support doping prevention and the development of educational programs for athletes about doping sources.

\section{Materials and Methods}

We searched scientific electronic databases for eligible studies, including PubMed, Google Scholar, Science Direct, and Web of Science. We followed the PRISMA guidelines for conducting systematic reviews (Figure 4) [59]. We conducted our search using the following keywords: "higenamine in dietary supplements", "higenamine detection", "higenamine in plants", " higenamine in plants detection", "higenamine in Nelumbo nucifera", "higenamine in Nandina domestica", "higenamine in Tinospora crispa", "higenamine in Aconitum", "higenamine in Gnetum parvifolium", and "higenamine in Asarum sieboldii". 
Identification of studies via databases and registers

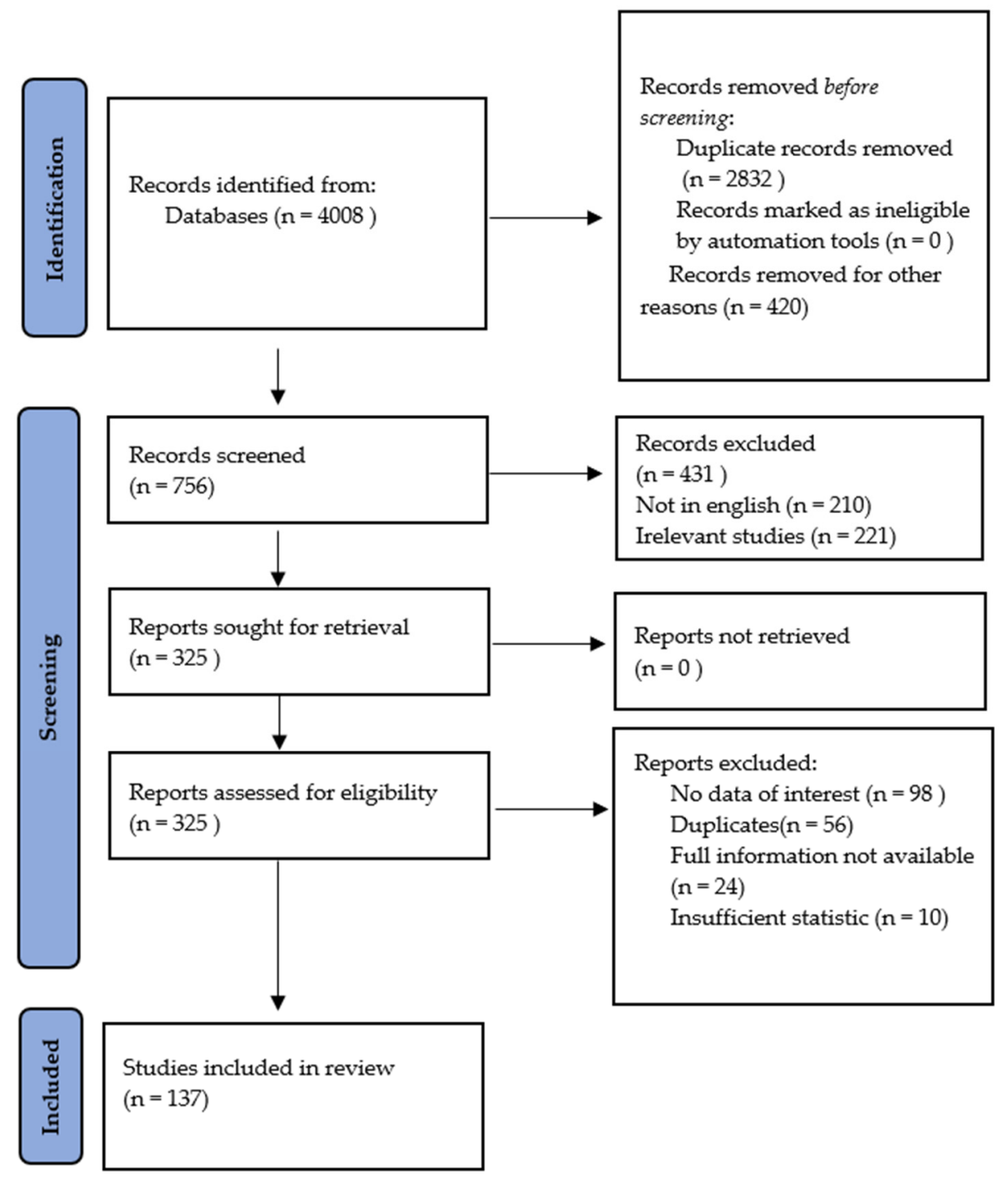

Figure 4. PRISMA 2020 flow diagram for new systematic reviews, which includes database and register searches only.

We discovered other relevant sources by inspecting the references of related articles. The program Zotero was used to generate the references in this paper.

The following eligibility criteria were used in selecting articles:

- Original articles that provide information on higenamine presence in plants;

- Manuscripts proving the presence of bioactive compounds in related plants;

- Studies providing methods for identification or quantification of higenamine in plants;

- Studies involving human, mammals, or biological samples investigating the relationship between the use of higenamine-containing plants and other possible effects.

Titles, abstracts, and full texts were screened. One researcher reviewed the whole text of the preselected publications to apply eligibility criteria, while a second researcher doublechecked the selections to verify that all studies were included. One author collected data and verified them with another author to avoid missing data. Only full-text original manuscripts written in English were included. Our last search was performed on 10 November 2021. 


\section{Results and Discussion}

Data from our bibliographic review indicate that higenamine is found in various plants, including Aconitum spp. [60,61], Tinospora crispa (Tinospora crispa (L.) Hook. f. \& Thomson) [62], Nandina domestica (Nandina domestica Thunb.) [63], Nelumbo nucifera (Nelumbo nucifera Gaertn.) [63-65], Gnetum parvifolium (Gnetum parvifolium (Warb.) W.C.Cheng) [25], Asarum siebodii (Asarum sieboldii Miq.) [60], and Aristolochia brasiliensis (Aristolochia brasiliensis Mart. \& Zucc.) [66]. Extracts from these plants are available as food supplements. Studies of higenamine detection in plants are summarized in Table 1. The data about Tinospora crispa are presented in Table 2.

Table 1. Methods for identification and quantification of higenamine in plant extracts.

\begin{tabular}{|c|c|c|c|c|}
\hline Plant Name & Plant Part & Investigation Methods & Main Results & Reference \\
\hline Nelumbo nucifera & dried leaf and seed & $\begin{array}{l}\text { QuEChERS } \\
\text { LC-MS/MS }\end{array}$ & $\begin{array}{l}\text { Higenamine was detected in dried } \\
\text { lotus leaf, dried lotus seeds at a } \\
\text { concentration of } 9667.6 \text { and } \\
1183.8 \mu \mathrm{g} / \mathrm{kg} \text {, respectively. }\end{array}$ & {$[64]$} \\
\hline Nelumbo nucifera & plumule & UPLC-DAD & $\begin{array}{l}21 \text { alkaloids were identified, } \\
\text { including higenamine. }\end{array}$ & [67] \\
\hline Nelumbo nucifera & root of embryo & $\begin{array}{l}\text { High-Performance Liquid } \\
\text { Chromatography with } \\
\text { a Fluorescent Chiral } \\
\text { Tagging Reagent }\end{array}$ & $\begin{array}{c}R \text {-(+)-higenamine in embryo of } \\
\text { N. nucifera was } \\
93.0 \pm 2.42 \mathrm{mg} / 100 \mathrm{~g}\end{array}$ & {$[68]$} \\
\hline Nelumbo nucifera & $\begin{array}{l}\text { seed, leaf stamen, } \\
\text { plumule, receptacle, } \\
\text { and rhizome node }\end{array}$ & UPLC and QToF-MS & $\begin{array}{l}\text { Higenamine was detected in } \\
\text { leaves and plumule }\end{array}$ & [69] \\
\hline Aconitum japonicum & root & $\begin{array}{c}\text { Column } \\
\text { chromatography }\end{array}$ & $\begin{array}{l}\text { Higenamine was isolated from } \\
\text { Aconitum Japonicum thumb. }\end{array}$ & {$[24]$} \\
\hline & & \multirow{6}{*}{ icELISA and HPLC. } & Higenamine amounts detected: & \multirow{6}{*}[60]{} \\
\hline Aconitum carmichaelii (roots) & roots & & $2.58 \times 10^{-1}-3.04 \mu \mathrm{g} / \mathrm{g}$ dry wt & \\
\hline Nandina domestica (fruit) & fruit & & $12.21 \mu \mathrm{g} / \mathrm{g}$ dry wt & \\
\hline Nandina domestica (leaf) & leaf & & $56.30 \mu \mathrm{g} / \mathrm{g}$ dry wt & \\
\hline Asarum siebodii (root) & root & & $31.07 \mu \mathrm{g} / \mathrm{g}$ dry wt & \\
\hline Evodia rutaecarpa (fruit) & fruit & & $6.48 \mu \mathrm{g} / \mathrm{g}$ dry wt & \\
\hline $\begin{array}{l}\text { Aconitum kusnezoffii } \\
\text { and Aconitum napiforme }\end{array}$ & root & HPLC & $\begin{array}{l}\text { Aconitum extracts contained } \\
8-19 \mu \mathrm{g} / \mathrm{g} \text { of higenamine }\end{array}$ & {$[61]$} \\
\hline $\begin{array}{l}\text { Aconitum carmichaelii } \\
\text { (Radix Aconiti } \\
\text { Lateralis Preparata) }\end{array}$ & root & $\begin{array}{l}\text { LC coupled with } \\
\text { MS/MS }\end{array}$ & $\begin{array}{l}\text { Concentration of higenamine in } \\
\text { different decoctions were: } \\
\text { Bifupian } 2.31 \pm 0.11 \mu \mathrm{g} / \mathrm{g} \\
\text { Heishunpian } 3.03 \pm 0.15 \mu \mathrm{g} / \mathrm{g}\end{array}$ & {$[70]$} \\
\hline $\begin{array}{l}\text { Aconitum carmichaelii } \\
\text { (Radix Aconiti } \\
\text { Lateralis Preparata) }\end{array}$ & root & LC-MS/MS & $\begin{array}{c}10 \text { of the identified compounds, } \\
\text { including quercetin, } \\
\text { pseudoephedrine, ephedrine, } \\
\beta \text {-asarone, methylephedrine, } \\
\alpha \text {-linolenic acid, cathine, ferulic } \\
\text { acid, nardosinone, and } \\
\text { higenamine accounted for most of } \\
\text { the beneficial effects of Mahuang } \\
\text { Fuzi Xixin in allergic rhinitis }\end{array}$ & {$[71]$} \\
\hline Gnetum parvifolium & lianas & NMR & $\begin{array}{l}5 \text { alkaloids were isolated, } \\
\text { including higenamine }\end{array}$ & [25] \\
\hline
\end{tabular}


Table 2. Studies of higenamine in human/mammals in various matrices.

\begin{tabular}{|c|c|c|c|}
\hline Study & Aim & Main Results & Ref. \\
\hline $\begin{array}{c}\text { The risk of adverse higenamine } \\
\text { analytical findings following oral } \\
\text { administration of } \\
\text { Plumula nelumbinis capsules }\end{array}$ & $\begin{array}{l}\text { Detection of higenamine in } \\
\text { urine samples }\end{array}$ & $\begin{array}{l}\text { The concentration of higenamine in } \\
\text { most urine sample groups exceeded the } \\
\text { limit specified by WADA. }\end{array}$ & [72] \\
\hline $\begin{array}{l}\text { Crude extract and purified components } \\
\text { isolated from the stems of } \\
\text { Tinospora crispa exhibit positive } \\
\text { inotropic effects on the isolated left } \\
\text { atrium of rats }\end{array}$ & $\begin{array}{l}\text { Investigation into the mechanism of } \\
\text { Tinospora crispa } \\
\text { bioactive compounds. }\end{array}$ & $\begin{array}{l}\text { Higenamine increased the left atrium's } \\
\text { contraction force. }\end{array}$ & [62] \\
\hline $\begin{array}{l}\text { Hypotensive and cardio-chronotropic } \\
\text { constituents of Tinospora crispa and } \\
\text { mechanisms of action on the } \\
\text { cardiovascular system of } \\
\text { anesthetized rats }\end{array}$ & $\begin{array}{l}\text { Identifying the active components } \\
\text { in Tinospora crispa extracts and } \\
\text { investigating the mechanisms of } \\
\text { action on blood pressure and heart } \\
\text { rate in anesthetized rats. }\end{array}$ & $\begin{array}{l}\text { Salsolinol, tyramine, and higenamine } \\
\text { acted via the adrenoreceptors, whereas } \\
\text { uridine and adenosine acted via } \\
\text { purinergic adenosine A2 and P2 } \\
\text { receptors to decrease blood pressure. }\end{array}$ & [73] \\
\hline $\begin{array}{l}\text { Counter effects of higenamine and } \\
\text { coryneine, components of Aconite root, } \\
\text { on acetylcholine release from motor } \\
\text { nerve terminal in mice }\end{array}$ & $\begin{array}{l}\text { Detection of higenamine } \\
\text { counteraction on } \\
\text { acetylcholine release. }\end{array}$ & $\begin{array}{l}\text { Higenamine increases Ach release by } \\
\text { activating } \beta \text {-adrenoreceptors. } \\
\text { Coryneine depresses Ach release by } \\
\text { acting on the motor nerve terminal. }\end{array}$ & [74] \\
\hline $\begin{array}{l}\beta_{2} \text {-adrenoceptor-mediated tracheal } \\
\text { relaxation induced by higenamine from } \\
\text { Nandina domestica Thunberg }\end{array}$ & $\begin{array}{l}\text { Identifying active components and } \\
\text { mechanism of action on } \\
\text { tracheal relaxation }\end{array}$ & $\begin{array}{l}\text { Higenamine is major constituent of } \\
\text { Nandina domestica crude extract, which } \\
\text { likely induces tracheal relaxation by } \\
\text { stimulating } \beta_{2} \text { adrenoceptors. }\end{array}$ & [42] \\
\hline $\begin{array}{l}\text { Biphasic tracheal relaxation induced by } \\
\text { higenamine and nantenine from } \\
\text { Nandina domestica Thunberg }\end{array}$ & $\begin{array}{l}\text { Comparing the effects of crude } \\
\text { extract, higenamine, and nantenine }\end{array}$ & $\begin{array}{l}\text { Higenamine relaxes the trachea by } \\
\beta \text {-adrenoceptor stimulation. }\end{array}$ & [75] \\
\hline $\begin{array}{l}\text { Determining higenamine and } \\
\text { coclaurine levels in human urine after } \\
\text { the administration of a throat lozenge } \\
\text { containing Nandina domestica fruit }\end{array}$ & $\begin{array}{l}\text { Investigation of throat lozenge } \\
\text { components and developing a } \\
\text { mass-spectrometry method for } \\
\text { quantifying higenamine and } \\
\text { coclaurine in human urine. }\end{array}$ & $\begin{array}{l}\text { The maximum concentrations of } \\
\text { higenamine and coclaurine were } \\
0.2-0.4 \text { and } 0.3-1.0 \mathrm{ng} / \mathrm{mL} \text {. They did } \\
\text { not exceed WADA's criteria. }\end{array}$ & [76] \\
\hline $\begin{array}{l}\text { Evaluation of anti-microbacterial } \\
\text { activity of higenamine using } \\
\text { Galleria mellonella as an in vivo } \\
\text { infection model }\end{array}$ & $\begin{array}{l}\text { Investigation of anti-microbacterial } \\
\text { effects of higenamine from } \\
\text { Aristolochia brasiliensis }\end{array}$ & $\begin{array}{l}\text { Higenamine was isolated from } \\
\text { Aristolochia brasiliensis and showed } \\
\text { anti-microbacterial activity. }\end{array}$ & [66] \\
\hline $\begin{array}{l}\text { A triple combination strategy of } \\
\text { UHPLC-MSn, hypolipidemic activity, } \\
\text { and transcriptome sequencing to unveil } \\
\text { the hypolipidemic mechanisms of } \\
\text { Nelumbo nucifera alkaloids }\end{array}$ & $\begin{array}{l}\text { Screening of Nelumbo nucifera } \\
\text { alkaloids for potential } \\
\text { hyperlipidemic effect. }\end{array}$ & $\begin{array}{c}35 \text { compounds were found in } \\
N \text {. nucifera alkaloid extraction. } \\
\text { Liensinine, higenamine, } \\
N \text {-norarmepavine nuciferine, } \\
N \text {-nornuciferine, } O \text {-nornuciferine, } \\
\text { coclaurine and armepavine showed } \\
\text { significant effects on hyperlipidemia. }\end{array}$ & [63] \\
\hline
\end{tabular}

\subsection{Nelumbo nucifera (Nelumbo nucifera Gaertn.)}

Nelumbo nucifera (sacred lotus) is an aquatic rhizomatous plant of the monogeneric family Nymphaeaceae. Nelumbo nucifera has peltate, membranous leaves up to $90 \mathrm{~cm}$ in diameter with tiny thorns along the long petiole. The flowers are approximately $10-25 \mathrm{~cm}$ in diameter, have many stamens and various colors, ranging from rosy to white. The inner part of the yellow rhizome contains air pockets that enable flotation in water. Fruits are green and ovoid with black, hard seeds arranged in whorls [77,78]. Nearly all parts of the lotus plant worldwide are used as vegetables. Reports on the therapeutic properties of lotus date back to 400 B.C. and were originally documented in the book Erya [79]. Nelumbo nucifera contains a wide range of chemical compounds: alkaloids, flavonoids, glycosides, terpenoids, fatty acids, steroids, minerals, and vitamins [80]. Compounds 
found in lotus are associated with various pharmaceutical effects. Flavonoids have been shown to have antioxidant activity [81]. Alkaloids also show strong cytoprotective activity, primarily liensinine, neferine, and roemerine [82].

Flavonoids have antiviral, hepatoprotective, anti-obesity, anti-inflammatory, anxiolytic effects, and alkaloids effective in treating cardiovascular diseases; they also have anti-inflammatory effects, decrease blood lipids, and have melanogenesis inhibitory activities [64,83-92]. Nuciferine, (-)-lirinidine $N$-methylasimilobine, and 2-hydroxy-1-methoxy6a,7-dehydroaporphine provide melanogenesis inhibitory activity [93]. There have been several studies investigating the phytochemistry of Nelumbo nucifera. It is rich in flavonoids and glycosides. It is also rich in alkaloids, including coclaurine, $4^{\prime}-N$-methyl coclaurine, nuciferine, higenamine, higenamine 4-O-glucoside, and nelumboferine [93-97]. Pei et al. detected 171 compounds from six different parts of the lotus in a recent study [69]. Higenamine was identified in the leaves and plumule.

$S$-(-)-higenamine was isolated from leaves and $R-(+)$-higenamine was isolated from the embryo of Nelumbo nucifera $[68,87]$.

Lotus plumule, also known as Plumula nelumbinis, and Lian Zi Xin, the bitter-tasting green embryo of lotus seeds, has long been used as tea in Asia. It has been used to treat mental health problems, sleeplessness, high-temperature fevers, and cardiovascular disease $[98,99]$.

Although the use of lotus extract has a rich history, randomized studies involving humans are limited.

However, there are some studies that investigated the pharmacokinetics of higenamine after the intake of lotus plumule. Yen et al. conducted a study where six human volunteers consumed $0.8 \mathrm{~g}$ of lotus plumule extract powder and $679.6 \mu \mathrm{g}$ of higenamine, respectively, three times a day for three days. HPLC-MS/MS was used to determine the amount of higenamine. The authors of this study recommended avoiding the intake of herbal products containing lotus plumule by professional athletes because it would result in high urinary concentrations of higenamine and violation of anti-doping rules. [100]. In another study, volunteers were administered Plumula nelumbinis capsules with a $0.34 \mathrm{~g} /$ capsule six times a day for seven days. Urine samples were analyzed with UPLC-MS/MS [72]. The concentration of higenamine in the urine of most sample groups from both studies was higher than the limit stated in the WADA regulations [49]. Lotus plumule herbal extract intake clearly poses a risk to anti-doping violation rules. These results suggest that athletes should avoid eating foods or medicines containing Plumula nelumbinis during and outside of competition.

\subsection{Tinospora crispa (Tinospora crispa (L.) Hook. f. E Thomson)}

Tinospora crispa (Menispermaceae) is a woody vine with large, heart-shaped leaves $6-12 \mathrm{~cm}$ long and 7-12 cm wide with small yellow or green flowers. The stems are long, fleshy, and thick, with numerous tubercles. Its petioles are 5-15 cm long [101]. Tinospora crispa is widely used in traditional medicine in Southeast Asia. This herb has been used as an antipyretic for treating rheumatism, diabetes, hypertension, stimulation of appetite, and maintaining good health [102]. The decoction of the stem has been used for its antipyretic, antimalarial, and anthelmintic properties, whereas the decoction of the whole plant is used in treating diabetes [103]. Fresh leaves are reportedly used on wounds [104]. Medicinal compounds are found in all parts of the plant (roots, leaves, and stems). Pharmacochemical studies indicate the presence of flavonoids and glycosides, including apigenin and genkwanin; alkaloids, including higenamine, tyramine, dihydrodiscretamin, columbamine, $N$-demethyl- $N$-formyldehydronornuciferine, $N$-formylasimilobine2- $O-\beta$ $D$-glucopyranoside, $N$-formylasimilobine2-O-beta- $D$-glucopyranosyl-(1->2)-beta- $D$ - glucopyranoside, $\mathrm{N}$-trans-feruloyltyramine, $\mathrm{N}$-formylnornuciferine, $\mathrm{N}$-formylanonaine, terpenoids and others such as adenosine, uridine, and adenine [105-109]. Extracts from the Tinospora crispa stem show high antioxidant activity, which can be measured with vitamin $\mathrm{C}$ and butylhydroxytoluene [110-112]. $N$-cis-feruloyltyramine, $N$ trans-feruloyltyramine, 
and secoisolariciresinol are responsible for antioxidant activity [111]. Borapetosides A and C from Tinospora crispa stem extracts correspond to anti-hypoglycemic effects [113-115]. Based on a recent study by Rakib et al., genkwanin has hepatoprotective components from Tinospora crispa [106].

Active compounds isolated from Tinospora crispa affect the cardiovascular system. Five active compounds were isolated by Praman et al., including higenamine, adenosine, uridine, salsolinol, and tyramine. [73]. These chemicals influenced blood pressure and heart rate in normal, anesthetized, and reserpinized rats. Adenosine and salsolinol both decreased heart rate and arterial blood pressure. Higenamine raised heart rate while lowering mean arterial blood pressure. In Tinospora crispa, higenamine was found in a racemic mixture of $R$ and $S$ enantiomers in concentrations from 0.001 to $0.3 \mathrm{mg} / \mathrm{kg}$ [62,73]. Study results have suggested that Tinospora crispa is a promising plant for treating many diseases. Although few human studies provide evidence of higher than recommended urinary concentrations of higenamine, our recommendation for athletes is to restrain their use of Tinospora crispa extracts. More comprehensive studies on the higenamine content of Tinospora crispa are required to understand the potential dangers of higenamine misuse for athletes.

\subsection{Aconitum spp.}

Aconitum is a major genus in the Ranunculaceae family, including over 400 species. The first use of the Aconitum species dates to 2000 years ago [116]. Despite many of the species in this genus being toxic, they have been used in China, Korea, Japan, and India as medical herbs, whereas the use of Aconitum in the United States and Europe is limited [117,118]. Plants from the Aconitum genus have long been used to treat heart failure and poor circulation [118]. Aconitum carmichaelii (Aconitum carmichaelii Debeaux.) is currently used in traditional Chinese medicine. Familiar derivates of Aconitum carmichaelii are Radix Aconiti praeparata and Radix Aconiti lateralis praeparata, called Chuanwu and Fuzi, respectively [119]. Fuzi is a processed form of the lateral root. The forms of Chuanwu and Fuzi depend on different processing approaches, including Shengfuzi, Yanfuzi, Heishunpian, and Baifupian, which were created to reduce toxicity [28]. Most phytochemical studies have focused on the plant's roots [119]. More than 120 chemical compounds, particularly alkaloids, have been isolated from Aconitum carmichaelii. Diterpene alkaloids are the main class of Aconitum plants, and they vary from nontoxic to fatal and poisonous. They can be separated into three groups: diester-diterpenoid alkaloids (DAs), monoester-diterpenoid alkaloids (MAs), and unesterified diterpenoid alkaloids (UAs). Among these alkaloids are also saponins, glycosides, and flavonoids. Diester-diterpenoid alkaloids such as hypaconitine, aconitine, and mesaconitine are responsible for toxicity and can induce arrhythmia or cardiac depression [8]. During processing methods such as decoction and steaming, diesterditerpenoid alkaloids hydrolyze in less toxic monoester-diterpenoid alkaloids so Aconitum's poisonous effect decreases significantly. Many new processing methods for Aconitum have been developed in recent years $[119,120]$. Decoctions are often combined with dried ginger, licorice, and ginseng [118,121]. Examples of these decoction combinations are Sini and Shenfu. New technologies enable Aconitum to be used as a safe plant. Alkaloids from Aconitum demonstrate analgesic, cardiovascular, anti-inflammatory, antioxidant, and anti-tumor activities [122].

Higenamine was discovered as a cardiotonic compound in 1976 [24]. Coryneine and salsolinol were also extracted from Radix Lateralis Preparata [74]. Higenamine was also detected in Aconitum kusnezoffii (Aconitum kusnezoffii Reichb) and Aconitum napiforme (Aconitum napiforme H.Lev. \& Vaniot) roots. $R-(+)$-higenamine in Aconitum preparations is ten times less than in the embryo of Nelumbo nucifera, [61]. icELISA and HPLC were used to identify S-(-)-higenamine in Aconitum carmichaelii roots. A study by Chung et al. showed a different concentration of $R-(+)$-higenamine in the processed and unprocessed roots of Aconitum carmichaelii at 12.2 and $18.3 \mu \mathrm{g} / \mathrm{g}$ [61]. Since then, higenamine has been detected in the decoctions Baifupian and Heishunpian in similar amounts ranging from 2.31 to 
$3.18 \mu \mathrm{g} / \mathrm{g}$. [70]. Nowadays, there are many processed products of Aconitum. For example, in the Chinese Pharmacopoeia 2015 around 50 herbal mixtures containing Aconitum are described [119]. Because these products are produced with different extraction methods the concentrations of higenamine might significantly vary. The safety of each Aconitum preparation must be evaluated before intake by professional athletes [61,71].

\subsection{Nandina domestica (Nandina domestica Thunb.)}

Nandina domestica is a plant from the Berberidaceae family. In Chinese traditional medicine, roots, leaves, stems, and fruits are primarily used to treat coughing and asthma [123]. Phytochemical analysis has recently revealed that major compounds from Nandina domestica are alkaloids [123-125]. Flavonoids and lignans are also present [126]. Nantenine is an alkaloid that mostly contributes to the pharmacological effectivity of Nandina domestica [42]. Higenamine is associated with tracheal relaxation from Nandina domestica through the stimulation of $\beta$ adrenoreceptors [75,127]. S-(-)-higenamine was detected in the leaf and fruit by icELISA and HPLC in the dry weight concentrations of 56.30 and $14.02 \mu \mathrm{g} / \mathrm{g}$, respectively [60]. Higenamine was also isolated as a racemic mixture [128]. In 2017, Okano et al. used LC-MS/MS for detecting higenamine and coclaurine in urine after using throat lozenges containing Nandina domestica fruit. The urinary concentration of higenamine and coclaurine grew but did not exceed the criteria set by WADA [76]. Therefore, not every product containing Nandina domestica poses a risk to athletes when following the label-recommended dosage. However, excessive, and prolonged intake must also be considered.

\subsection{Gnetum parvifolium (Gnetum parvifolium (Warb.) W.C.Cheng)}

Gnetum parvifolium is a green woody vine from the Gnetaceae family. Phytochemical studies have revealed that it is rich in stilbenoids and flavonoids $[129,130]$. The roots and stems are traditionally used to treat rheumatism, chronic bronchitis, respiratory infections, and traumatic injuries [129-131]. Stilbenoids from the lianas of the plant have antiinflammatory activity [129]. Resveratrol isorhapontigenin, piceatannol, and rhaponiticin have been identified as xanthine oxidase inhibitors [131]. Higenamine was first isolated from the ethanolic extract of lianas in 1980, then again in 1998 as a racemic mixture of $S$-(-)-higenamine and $R-(+)$-higenamine [25]. There are no data for the exact concentrations of higenamine in Gnetum parvifolium.

\subsection{Asarum sieboldii (Asarum sieboldii Miq.)}

Asarum sieboldii from the Aristolochiaceae family is often used in Japan, Korea, and China [132]. It has been officially classified in the Chinese Pharmacopoeia for its analgesic and antitussive effects [133]. Essential oils such as limonene, asarylketone, cineol, safrole, lignans, and alkaloids such as higenamine are the main compounds of the plant. There is evidence for the anti-inflammatory [134], anti-bacterial [135], anti-fungal [132], and anti-cancer activity [136] effects of Asarum sieboldii. Bioactive compounds of Asari radix, including methyl eugenol, sesamin, asarinin echinacoside, vanillic acid, and kakuol, are useful in treating allergies [137-139]. Xixin (Asari Radix et Rhizoma) can be radix and rhizoma from Asarum sieboldii or Asarum heterotropoides (Asarum heterotropoides F. Schmidt) [140]. Kosuge et al. isolated higenamine as a racemic mixture from Asarum heterotropoides and demonstrated how it is responsible for antitussive effects [141]. S-(-)-higenamine was also isolated from Asarum sieboldii roots in the dry weight concentrations of $23.08 \mu \mathrm{g} / \mathrm{g}$ with HPLC and $31.07 \mu \mathrm{g} / \mathrm{g}$ in dry weight with icELISA [60]. Asari Radix et Rhizoma is part of the recipe for Mahuang Fuzi Xixin [142], which contains Ephedrae Herba (Ma Huang), Radix Aconiti Lateralis Preparata (Fu Zi), Asarum Heterotropoides, or Asarum sieboldii (Xi Xin) and is used to treat asthma in traditional Chinese medicine [143]. All plants potentially contain performance-enhancing effects, and two of them contain higenamine. Combining such products can lead to higher amounts of higenamine and risks unintentional doping. 


\subsection{Risk Assessment of Intake Higenamine-Containing Plants}

According to our research, the concentration of higenamine in lotus plumule was higher than in other plants. Investigations into the pharmacokinetics of lotus plumule capsules regulated with good manifesting practice and commercially used powder showed that both pose risks of unintentional doping [72,100]. Yen et al. investigated the total amount of alkaloids in six herbal extract products of Plumule Nelumbis and five crude lotus plumule. The concentration of higenamine varied from 263.9 to $969.5 \mu \mathrm{g} / \mathrm{g}$. Different preparation methods lead to changes in higenamine concentrations. Furthermore, samples analyzed from six individuals show significant differences in higenamine amounts [100]. These results relate to UGT1A9 (UDP glucuronosyltransferase family 1 member A9), which is responsible for higenamine glucuronidation [144]. Nandina domestica (leaf) also has high concentrations. A total of $56.30 \mu \mathrm{g} / \mathrm{g}$ in dry weight was detected by icELISA. Nuntawong et al. compared two methods, icELISA and HPLC, where the higenamine concentrations detected with HPLC were lower (34.69 $\mu \mathrm{g} / \mathrm{g}$ in dry weight) [60]. The same study showed that candy containing Nandina domestica does not contain higenamine and that urinary samples collected from the consumption of throat lozenges containing Nandina domestica fruit contained $0.2-0.4 \mathrm{ng} / \mathrm{mL}$ of higenamine. Nandina domestica fruit contains less higenamine than the leaves [60], and pharmacokinetic studies on Nandina domestica leaf-based products are missing. Considering that Nandina domestica leaf is also used to treat cough and asthma, we believe that more studies are needed to understand its safety and risk factors fully. Studies on Nandina domestica and higenamine's effects on tracheal relaxation provide more reasons to restrain from the use of Nandina domestica products [75]. Although there are low concentrations of higenamine in Tinospora crispa, studies on crude stem extracts demonstrated adverse effects on blood pressure and left atrium contraction in rats, which correlated with higenamine presence [62,73]. More studies on the effects of higenamine, including antimicrobial effects from Aristolochia brasiliensis, hypolipidemic effects from Nelumbo nucifera in mammals, and various matrices are summarized in Table 2. Since higenamine's effect on metabolism is unclear, UGT1A9 can vary by individual. Different extraction methods can lead to different concentrations of alkaloids. Some decoctions such as Mahuang Fuzi Xixin combine plants that contain higenamine. Before more comprehensive studies are conducted to ensure the safety of the aforementioned plants, athletes should restrict their use of any products containing Nelumbo nucifera, Nandina domestica, Tinospora crispa, Aconitum spp., Aristolochia brasiliensis, Asarum sieboldii, Asarum heterotropoides, and Gnetum parvifolium.

\section{Conclusions}

Unintentional doping has become a serious and important scientific and social task in the previous two decades. The primary sources of unintentional doping are food supplements that contain prohibited compounds, contaminated food supplements, and some plant extracts. However, unintentional doping is preventable.

The key points of this prevention are defining the sources of unintentional doping, educating athletes about the sources of unintentional doping, and helping athletes analyze and control which food supplements are included in their diet.

Higenamine is a good example of a pharmacologically active compound included in WADA's prohibited list. It is also found in many plant extracts used by humanity for a long period of time and food supplements. The labeling of most commercial products is unclear regarding the higenamine content of a specific plant or extract. Nelumbo nucifera, Nandina domestica, Tinospora crispa, Aconitum spp., Aristolochia brasiliensis, Asarum sieboldii, Asarum heterotropoides, and Gnetum parvifolium are used for various allergic diseases, rheumatism, asthma, diabetes, hypertension, etc. Considering that plant species are receiving more attention for treatments worldwide and the rising trend of plant-based dietary supplements, it is important to include all plants containing higenamine in educational programs for athletes. 
Our recommendation to athletes is to restrain their use of those plants. More comprehensive studies evaluating the risks and benefits of using certain reported plants would be valuable.

Knowledge about herbal medicine components and further investigation into plants is important so that athletes can be confident that herbal medicines are safe to use.

Author Contributions: Conceptualization, V.R.K., K.I. and S.I.; data curation, V.R.K. and S.I.; writing —original draft preparation, V.R.K. and S.I.; visualization, V.R.K. and S.I.; writing-review and editing, K.I. and S.I.; supervision, K.I. All authors have read and agreed to the published version of the manuscript.

Funding: This research received no external funding.

Institutional Review Board Statement: Not applicable.

Informed Consent Statement: Not applicable.

Data Availability Statement: Not applicable.

Conflicts of Interest: The authors declare no conflict of interest.

\section{References}

1. Zhang, N.; Lian, Z.; Peng, X.; Li, Z.; Zhu, H. Applications of higenamine in pharmacology and medicine. J. Ethnopharmacol. 2017, 196, 242-252. [CrossRef] [PubMed]

2. Garthe, I.; Maughan, R.J. Athletes and supplements: Prevalence and perspectives. Int. J. Sport Nutr. Exerc. Metab. 2018, 28, 126-138. [CrossRef] [PubMed]

3. Williams, M. Dietary supplements and sports performance: Herbals. J. Int. Soc. Sports Nutr. 2006, 3, 1. [CrossRef]

4. Herbold, N.H.; Visconti, B.K.; Frates, S.; Bandini, L. Traditional and nontraditional supplement use by collegiate female varsity athletes. Int. J. Sport Nutr. Exerc. Metab. 2004, 14, 586-593. [CrossRef] [PubMed]

5. Cooper, E.R.; McGrath, K.C.Y.; Li, X.; Heather, A.K. Androgen bioassay for the detection of nonlabeled androgenic compounds in nutritional supplements. Int. J. Sport Nutr. Exerc. Metab. 2018, 28, 10-18. [CrossRef]

6. Parr, M.; Pokrywka, A.; Kwiatkowska, D.; Schänzer, W. Ingestion of designer supplements produced positive doping cases unexpected by the athletes. Biol. Sport Inst. Sport 2011, 28, 153-157. [CrossRef]

7. Reeuwijk, N.M.; Venhuis, B.J.; de Kaste, D.; Hoogenboom, R.L.A.P.; Rietjens, I.M.C.M.; Martena, M.J. Active pharmaceutical ingredients detected in herbal food supplements for weight loss sampled on the Dutch market. Food Addit. Contam. Part A 2014, 31, 1783-1793. [CrossRef]

8. Woo, H.; Kim, J.W.; Han, K.M.; Lee, J.H.; Hwang, I.S.; Lee, J.H.; Kim, J.; Kweon, S.J.; Cho, S.; Chae, K.R.; et al. Simultaneous analysis of 17 diuretics in dietary supplements by HPLC and LC-MS/MS. Food Addit. Contam. Part A 2013, 30, 209-217. [CrossRef]

9. Venhuis, B.; Keizers, P.; van Riel, A.; de Kaste, D. A cocktail of synthetic stimulants found in a dietary supplement associated with serious adverse events: A cocktail of synthetic stimulants found in a dietary supplement associated with serious adverse events. Drug Test. Anal. 2014, 6, 578-581. [CrossRef]

10. Kerpel dos Santos, M.; Gleco, E.; Davidson, J.T.; Jackson, G.P.; Pereira Limberger, R.; Arroyo, L.E. DART-MS/MS screening for the determination of 1,3-dimethylamylamine and undeclared stimulants in seized dietary supplements from Brazil. Forensic Chem. 2018, 8, 134-145. [CrossRef]

11. Russo, G.; Barbato, F.; Grumetto, L. A validated LC/UV method for the determination of four adulterating drugs in herbal slimming capsules. J. Pharm. Biomed. Anal. 2016, 117, 436-445. [CrossRef]

12. Baume, N.; Mahler, N.; Kamber, M.; Mangin, P.; Saugy, M. Research of stimulants and anabolic steroids in dietary supplements. Scand. J. Med. Sci. Sports 2006, 16, 41-48. [CrossRef] [PubMed]

13. Green, G.A.; Catlin, D.H.; Starcevic, B. Analysis of over-the-counter dietary supplements. Clin. J. Sport Med. 2001, 11, 254-259. [CrossRef] [PubMed]

14. Martello, S.; Felli, M.; Chiarotti, M. Survey of nutritional supplements for selected illegal anabolic steroids and ephedrine using LC-MS/MS and GC-MS methods, respectively. Food Addit. Contam. 2007, 24, 258-265. [CrossRef] [PubMed]

15. Van Poucke, C.; Detavernier, C.; Van Cauwenberghe, R.; Van Peteghem, C. Determination of anabolic steroids in dietary supplements by liquid chromatography-tandem mass spectrometry. Anal. Chim. Acta 2007, 586, 35-42. [CrossRef] [PubMed]

16. Ahmad, R.; Ahmad, N.; AlHudaithi, N.; AlHebshi, A.; Bukhari, A. Extraction and UHPLC-DAD detection of undeclared substances in market-available dietary supplements and slimming products in Eastern region, Saudi Arabia: An application of principal component analysis. Biomed. Chromatogr. 2020, 34, e4698. [CrossRef]

17. Austin, K.G.; Travis, J.; Pace, G.; Lieberman, H.R. Analysis of 1,3 dimethylamylamine concentrations in Geraniaceae, Geranium oil and dietary supplements: 1,3 dimethylamylamine, dietary supplements, Geranium oil and Geraniaceae. Drug Test. Anal. 2014, 6, 797-804. [CrossRef] 
18. World Anti-Doping Agency. Wada-Reference Guide to 2015 Code. Available online: https://www.wada-ama.org/sites/default/ files/resources/files/wada-reference-guide-to-2015-code.pdf (accessed on 25 October 2021).

19. Stadler, R.; Zenk, M.H. A revision of the generally accepted pathway for the biosynthesis of the benzyltetrahydroisoquinoline alkaloid reticuline. Liebigs Ann. Chem. 1990, 1990, 555-562. [CrossRef]

20. Stöckigt, J.; Antonchick, A.P.; Wu, F.; Waldmann, H. The Pictet-Spengler reaction in Nature and in organic chemistry. Angezw. Chem. Int. Ed. 2011, 50, 8538-8564. [CrossRef]

21. Samanani, N.; Facchini, P.J. Purification and characterization of norcoclaurine synthase. J. Biol. Chem. 2002, 277, 33878-33883. [CrossRef]

22. Ghirga, F.; Quaglio, D.; Ghirga, P.; Berardozzi, S.; Zappia, G.; Botta, B.; Mori, M.; D'Acquarica, I. Occurrence of enantioselectivity in Nature: The case of (S)-Norcoclaurine: Enantioselectivity in Nature. Chirality 2016, 28, 169-180. [CrossRef] [PubMed]

23. Koshiyama, H.; Ohkuma, H.; Kawaguchi, H.; Hsu, H.; Chen, Y. Isolation of 1-(p-hydroxybenzyl)-6,7-dihydroxy-1,2,3,4tetrahydroisoquinoline (demethylcoclaurine), an active alkaloid from Nelumbo nucifera. Chem. Pharm. Bull. 1970, 18, 2564-2568. [CrossRef]

24. Kosuge, T.; Yokota, M. Studies on cardiac principle of Aconite root. Chem. Pharm. Bull. 1976, 24, 176-178. [CrossRef] [PubMed]

25. Xu, Q.; Lin, M. Benzylisoquinoline alkaloids from Gnetum parvifolium. J. Nat. Prod. 1999, 62, 1025-1027. [CrossRef] [PubMed]

26. Pyo, M.K.; Lee, D.-H.; Kim, D.-H.; Lee, J.-H.; Moon, J.-C.; Chang, K.C.; Yun-Choi, H.S. Enantioselective synthesis of (R)-(+)- and (S)-(-)-higenamine and their analogues with effects on platelet aggregation and experimental animal model of disseminated intravascular coagulation. Bioorg. Med. Chem. Lett. 2008, 18, 4110-4114. [CrossRef]

27. Park, J.E.; Kang, Y.J.; Park, M.K.; Lee, Y.S.; Kim, H.J.; Seo, H.G.; Lee, J.H.; Hye Sook, Y.-C.; Shin, J.S.; Lee, H.W.; et al. Enantiomers of higenamine inhibit LPS-induced INOS in a macrophage cell line and improve the survival of mice with experimental endotoxemia. Int. Immunopharmacol. 2006, 6, 226-233. [CrossRef]

28. Singhuber, J.; Zhu, M.; Prinz, S.; Kopp, B. Aconitum in traditional Chinese medicine-A valuable drug or an unpredictable Risk? J. Ethnopharmacol. 2009, 126, 18-30. [CrossRef]

29. Lee, S.-R.; Schriefer, J.M.; Gunnels, T.A.; Harvey, I.C.; Bloomer, R.J. Acute oral intake of a higenamine-based dietary supplement increases circulating free fatty acids and energy expenditure in human subjects. Lipids Health Dis. 2013, 12, 148. [CrossRef]

30. Biesterbos, J.W.H.; Sijm, D.T.H.M.; van Dam, R.; Mol, H.G.J. A Health risk for consumers: The presence of adulterated food supplements in the Netherlands. Food Addit. Contam. Part A 2019, 36, 1273-1288. [CrossRef]

31. Feng, S.; Jiang, J.; Hu, P.; Zhang, J.; Liu, T.; Zhao, Q.; Li, B. A Phase I study on pharmacokinetics and pharmacodynamics of higenamine in healthy Chinese subjects. Acta Pharmacol. Sin. 2012, 33, 1353-1358. [CrossRef]

32. Kimura, I.; Makino, M.; Takamura, Y.; Islam, M.A.; Kimura, M. Positive chronotropic and inotropic effects of higenamine and its enhancing action on the aconitine-induced tachyarrhythmia in isolated murine atria. Jpn. J. Pharmacol. 1994, 66, 75-80. [CrossRef] [PubMed]

33. Liu, X.; Wagner, H.N.; Tao, S. Measurement of effects of the Chinese herbal medicine higenamine on left ventricular function using a cardiac probe. Eur. J. Nucl. Med. 1983, 8, 233-236. [CrossRef] [PubMed]

34. Calvert, R.; Vohra, S.; Ferguson, M.; Wiesenfeld, P. A beating heart cell model to predict cardiotoxicity: Effects of the dietary supplement ingredients higenamine, phenylethylamine, ephedrine and caffeine. Food Chem. Toxicol. 2015, 78, 207-213. [CrossRef] [PubMed]

35. Chen, Y.; Guo, B.; Zhang, H.; Hu, L.; Wang, J. Higenamine, a dual agonist for $\beta_{1}$ - and $\beta_{2}$-adrenergic receptors identified by screening a traditional Chinese medicine library. Planta Med. 2019, 85, 738-744. [CrossRef]

36. Zhang, N.; Qu, K.; Wang, M.; Yin, Q.; Wang, W.; Xue, L.; Fu, H.; Zhu, H.; Li, Z. Identification of higenamine as a novel $\alpha_{1}$-adrenergic receptor antagonist: Higenamine, a novel a1-adrenergic receptor antagonist. Phytother. Res. 2019, 33, 708-717. [CrossRef]

37. Zhu, J.; Ling, W.; Xue, C.; Zhou, Z.; Zhang, Y.; Yan, C.; Wu, M. Higenamine attenuates cardiac fibroblast abstract and fibrosis via inhibition of TGF-B1/Smad signaling. Eur. J. Pharmacol. 2021, 900, 174013. [CrossRef]

38. Bai, X.; Ding, W.; Yang, S.; Guo, X. Higenamine inhibits IL-1 $\beta$-induced inflammation in human nucleus pulposus cells. Biosci. Rep. 2019, 39, BSR20190857. [CrossRef]

39. Lee, Y.S.; Kang, Y.J.; Kim, H.J.; Park, M.K.; Seo, H.G.; Lee, J.H.; Yun-Choi, H.S.; Chang, K.C. Higenamine reduces apoptotic cell death by induction of heme oxygenase-1 in rat myocardial ischemia-reperfusion injury. Apoptosis 2006, 11, 1091-1100. [CrossRef]

40. Romeo, I.; Parise, A.; Galano, A.; Russo, N.; Alvarez-Idaboy, J.R.; Marino, T. The antioxidant capability of higenamine: Insights from theory. Antioxidants 2020, 9, 358. [CrossRef]

41. Bai, G.; Yang, Y.; Shi, Q.; Liu, Z.; Zhang, Q.; Zhu, Y. Identification of higenamine in Radix Aconiti Lateralis Preparata as a beta2-adrenergic receptor agonist. Acta Pharmacol. Sin. 2008, 29, 1187-1194. [CrossRef]

42. Tsukiyama, M.; Ueki, T.; Yasuda, Y.; Kikuchi, H.; Akaishi, T.; Okumura, H.; Abe, K. $\beta_{2}$-adrenoceptor-mediated tracheal relaxation induced by higenamine from Nandina domestica Thunberg. Planta Med. 2009, 75, 1393-1399. [CrossRef] [PubMed]

43. Yun-Choi, H.S.; Pyo, M.K.; Park, K.M.; Chang, K.C.; Lee, D.H. Anti-thrombotic effects of higenamine. Planta Med. 2001, 67, 619-622. [CrossRef] [PubMed]

44. World Anti-Doping Agency (WADA). What Is Prohibited. Available online: https://www.wada-ama.org/en/content/what-isprohibited (accessed on 25 October 2021).

45. Cohen, P.A.; Travis, J.C.; Keizers, P.H.J.; Boyer, F.E.; Venhuis, B.J. The Stimulant higenamine in weight loss and sports supplements. Clin. Toxicol. 2019, 57, 125-130. [CrossRef] 
46. Deldicque, L.; Francaux, M. Potential harmful effects of dietary supplements in sports medicine. Curr. Opin. Clin. Nutr. Metab. Care 2016, 19, 439-445. [CrossRef] [PubMed]

47. Bloomer, R.; Schriefer, J.; Gunnels, T. Clinical safety assessment of oral higenamine supplementation in healthy, young men. Hum. Exp. Toxicol. 2015, 34, 935-945. [CrossRef]

48. Jeter, J.; DeZee, K.J.; Kennedy, L. A case of paraspinal muscle rhabdomyolysis in a 22-year-old male after ingesting a supplement containing higenamine. Mil. Med. 2015, 180, e847-e849. [CrossRef]

49. World Anti-Doping Agency (WADA). WADA Technical Document TD2019MRPL-Minimum Required Performance Levels for Detection and Identification of Non-Threshold Substances. 2019. Available online: www.wada-ama.org/sites/default/files/ resources / files/td2019mrpl_eng.pdf (accessed on 15 October 2021).

50. Feng, S.; Hu, P.; Jiang, J. Determination of higenamine in human plasma and urine using liquid chromatography coupled to positive electrospray ionization tandem mass spectrometry. J. Chromatogr. B 2011, 879, 763-768. [CrossRef]

51. Stajić, A.; Anđelković, M.; Dikić, N.; Rašić, J.; Vukašinović-Vesić, M.; Ivanović, D.; Jančić-Stojanović, B. Determination of higenamine in dietary supplements by UHPLC/MS/MS Method. J. Pharm. Biomed. Anal. 2017, 146, 48-52. [CrossRef]

52. Grucza, K.; Kwiatkowska, D.; Kowalczyk, K.; Wicka, M.; Szutowski, M.; Chołbiński, P. Analysis for higenamine in urine by means of ultra-high-performance liquid chromatography-tandem mass spectrometry: Interpretation of results. Drug Test. Anal. 2018, 10, 1017-1024. [CrossRef]

53. Grucza, K.; Kowalczyk, K.; Wicka, M.; Szutowski, M.; Bulska, E.; Kwiatkowska, D. The Use of a valid and straightforward method for the identification of higenamine in dietary supplements in view of anti-doping rule violation cases. Drug Test. Anal. 2019, 11, 912-917. [CrossRef]

54. Feng, Y.-R.; Wang, B.; Li, G.-J.; Kang, W.-J.; Lian, K.-Q.; Lu, X.-L. Determination of higenamine in multi-Matrix by gas chromatography-mass spectrometry combined with derivatization technology. J. Food Drug Anal. 2020, 28, 124-131. [CrossRef] [PubMed]

55. World Anti-Doping Agency. 2020 Anti-Doping Testing Figures. Available online: https:/ /www.wada-ama.org/sites/default/ files/resources/files/2020_anti-doping_testing_figures_en.pdf (accessed on 1 October 2021).

56. U.S. Anti-Doping Agency. Matthew McCullough Accepts Doping Sanction. USADA. Available online: https://www.usada.org/ sanction/matthew-mccullough-accepts-doping-sanction/ (accessed on 31 October 2021).

57. U.S. Anti-Doping Agency. U.S. Triathlon Athlete Mallory Schafer Accepts Sanction for Anti-Doping Rule Violation. USADA. Available online: https:/ / www.usada.org/sanction/mallory-schafer-accepts-doping-sanction/ (accessed on 30 October 2021).

58. U.S. Anti-Doping Agency. Talina Le Accepts Doping Sanction. Available online: https://www.usada.org/sanction/talina-leaccepts-doping-sanction/ (accessed on 29 October 2021).

59. Page, M.J.; McKenzie, J.E.; Bossuyt, P.M.; Boutron, I.; Hoffmann, T.C.; Mulrow, C.D.; Shamseer, L.; Tetzlaff, J.M.; Akl, E.A.; Brennan, S.E.; et al. The PRISMA 2020 statement: An updated guideline for reporting systematic reviews. BMJ 2021, 372, n71. [CrossRef] [PubMed]

60. Nuntawong, P.; Tanaka, H.; Sakamoto, S.; Morimoto, S. ELISA for the detection of the prohibited doping agent higenamine. Planta Med. 2020, 86, 760-766. [CrossRef] [PubMed]

61. Chung, K.-S.; YunChoi, H.-S.; Hahn, Y.-H. High performance liquid chromatographic analyses of higenamine enantiomers in Aconite roots. Nat. Prod. Sci. 2000, 6, 20-24.

62. Praman, S.; Mulvany, M.J.; Williams, D.E.; Andersen, R.J.; Jansakul, C. Crude extract and purified components isolated from the stems of Tinospora crispa exhibit positive inotropic effects on the isolated left atrium of rats. J. Ethnopharmacol. 2013, 149, 123-132. [CrossRef]

63. Yang, J.; Zhang, Y.; Jiang, L.; Li, C.; Sun, Z.; Zhang, Y.; Lin, T.; Jiang, Y.; Liu, B. A triple combination strategy of UHPLC-MSn, hypolipidemic activity and transcriptome sequencing to unveil the hypolipidemic mechanism of Nelumbo nucifera alkaloids. $J$. Ethnopharmacol. 2022, 282, 114608. [CrossRef]

64. Wang, H.; Tang, Y.; Zhao, X.; Ye, C.; Guo, S.; Luo, J.; Xiong, L.; Cao, W.; Wu, J.; Wang, P. Determination of higenamine in Chinese herbal medicine, condiments, and topical medicine by QuEChERS combined with liquid chromatography-tandem mass spectrometry. Chin. J. Chromatogr. 2019, 37, 1036. [CrossRef]

65. Cheng, Q.; Shou, L.; Chen, C.; Shi, S.; Zhou, M. Application of ultra-high-performance liquid chromatography coupled with LTQ-qrbitrap mass spectrometry for identification, confirmation and quantitation of illegal adulterated weight-loss drugs in plant dietary supplements. J. Chromatogr. B 2017, 1064, 92-99. [CrossRef]

66. Erasto, P.; Omolo, J.; Sunguruma, R.; Munissi, J.J.; Wiketye, V.; de Konig, C.; Ahmed, A.F. Evaluation of antimycobacterial activity of higenamine using Galleria Mellonella as an in vivo infection model. Nat. Prod. Bioprospecting 2018, 8, 63-69. [CrossRef]

67. Lin, Z.; Yang, R.; Guan, Z.; Chen, A.; Li, W. Ultra-performance LC separation and quadrupole time-of-flight MS identification of major alkaloids in Plumula nelumbinis: Novel alkaloids from Plumula nelumbinis. Phytochem. Anal. 2014, 25, 485-494. [CrossRef]

68. Hong, H.; Lee, Y.-I.; Jin, D. Determination of R-(+)-Higenamine enantiomer in Nelumbo nucifera by high-performance liquid chromatography with a fluorescent chiral tagging reagent. Microchem. J. 2010, 96, 374-379. [CrossRef]

69. Pei, H.; Su, W.; Gui, M.; Dou, M.; Zhang, Y.; Wang, C.; Lu, D. Comparative analysis of chemical constituents in different parts of lotus by UPLC and QToF-MS. Molecules 2021, 26, 1855. [CrossRef] [PubMed] 
70. Guo, N.; Yang, D.; Ablajan, K.; Niu, X.; Fan, B.; Wang, Z.; Dai, J.; Wu, X.; Liu, B. Simultaneous quantitation of seven alkaloids in processed Fuzi decoction by rapid resolution liquid chromatography coupled with tandem mass spectrometry: Liquid chromatography. J. Sep. Sci. 2013, 36, 1953-1958. [CrossRef] [PubMed]

71. Liang, X.; Liu, C.-S.; Xia, T.; Tang, Q.-F.; Tan, X.-M. Identification of active compounds of Mahuang Fuzi Xixin decoction and their mechanisms of action by LC-MS/MS and network pharmacology. Evid. Based Complement. Alternat. Med. 2020, 2020, 3812180. [CrossRef]

72. Yan, K.; Wang, X.; Wang, Z.; Wang, Y.; Luan, Z.; Gao, X.; Wang, R. the risk of higenamine adverse analytical findings following oral administration of Plumula nelumbinis Capsules. Drug Test. Anal. 2019, 11, 1731-1736. [CrossRef]

73. Praman, S.; Mulvany, M.J.; Williams, D.E.; Andersen, R.J.; Jansakul, C. hypotensive and cardio-chronotropic constituents of tinospora crispa and mechanisms of action on the cardiovascular system in anesthetized rats. J. Ethnopharmacol. 2012, 140, 166-178. [CrossRef]

74. Nojima, H.; Okazaki, M.; Kimura, I. Counter effects of higenamine and coryneine, components of Aconite Root, on acetylcholine release from motor nerve terminal in mice. J. Asian Nat. Prod. Res. 2000, 2, 195-203. [CrossRef]

75. Ueki, T.; Akaishi, T.; Okumura, H.; Morioka, T.; Abe, K. Biphasic tracheal relaxation induced by higenamine and nantenine from Nandina domestica THUNBERG. J. Pharmacol. Sci. 2011, 115, 254-257. [CrossRef]

76. Okano, M.; Sato, M.; Kageyama, S. Determination of higenamine and coclaurine levels in human urine after the administration of a throat lozenge containing NANDINA DOMESTICA fruit. Drug Test. Anal. 2017, 9, 1788-1793. [CrossRef]

77. Moro, C.F.; Yonekura, M.; Kouzuma, Y.; Agrawal, G.K.; Rakwal, R. Lotus-A source of food and medicine: Current Status and future perspectives in context of the seed proteomics. Int. J. Life Sci. 2013, 7, 1-5. [CrossRef]

78. Paudel, K.R.; Panth, N. Phytochemical profile and biological activity of Nelumbo nucifera. Evid. Based Complement. Alternat. Med. 2015, 2015, 789124. [CrossRef]

79. Guo, H.B. Cultivation of Lotus (Nelumbo nucifera Gaertn. Ssp. Nucifera) and its utilization in China. Genet. Resour. Crop Evol. 2009, 56, 323-330. [CrossRef]

80. Sharma, B.R.; Gautam, L.N.S.; Adhikari, D.; Karki, R. A comprehensive review on chemical profiling of Nelumbo nucifera: Potential for drug development: Phytochemical profiling of Lotus. Phytother. Res. 2017, 31, 3-26. [CrossRef]

81. Zhu, M.-Z.; Wu, W.; Jiao, L.-L.; Yang, P.-F.; Guo, M.-Q. Analysis of flavonoids in Lotus (Nelumbo nucifera) leaves and their antioxidant activity using macroporous resin chromatography coupled with LC-MS/MS and antioxidant biochemical assays Molecules 2015, 20, 10553-10565. [CrossRef] [PubMed]

82. Xie, Y.; Zhang, Y.; Zhang, L.-T.; Zeng, S.-X.; Guo, Z.-B.; Zheng, B.-D. Protective effects of alkaloid compounds from Nelumbinis Plumula on tert-butyl hydroperoxide-induced oxidative stress. Molecules 2013, 18, 10285-10300. [CrossRef]

83. Liu, Y.; Ma, S.; Ibrahim, S.A.; Li, E.; Yang, H.; Huang, W. Identification and antioxidant properties of polyphenols in Lotus Seed epicarp at different ripening stages. Food Chem. 2015, 185, 159-164. [CrossRef]

84. Lim, S.S.; Jung, Y.J.; Hyun, S.K.; Lee, Y.S.; Choi, J.S. Rat lens aldose reductase inhibitory constituents of Nelumbo nucifera Stamens: Rat lens aldolase and Nelumbo nucifera. Phytother. Res. 2006, 20, 825-830. [CrossRef]

85. Tian, W.; Zhi, H.; Yang, C.; Wang, L.; Long, J.; Xiao, L.; Liang, J.; Huang, Y.; Zheng, X.; Zhao, S.; et al. Data on chemical composition of alkaloids of Plumula nelumbinis and antioxidant activity from thirteen habitats in China. Data Brief 2018, 21, 1591-1597. [CrossRef]

86. Liu, S.-H.; Lu, T.-H.; Su, C.-C.; Lay, I.-S.; Lin, H.-Y.; Fang, K.-M.; Ho, T.-J.; Chen, K.-L.; Su, Y.-C.; Chiang, W.-C.; et al. Lotus leaf (Nelumbo nucifera) and its active constituents prevent inflammatory responses in macrophages via JNK/NF-KB signaling pathway. Am. J. Chin. Med. 2014, 42, 869-889. [CrossRef]

87. Kashiwada, Y.; Aoshima, A.; Ikeshiro, Y.; Chen, Y.-P.; Furukawa, H.; Itoigawa, M.; Fujioka, T.; Mihashi, K.; Cosentino, L.M.; Morris-Natschke, S.L.; et al. Anti-HIV benzylisoquinoline alkaloids and flavonoids from the leaves of Nelumbo nucifera, and structure-activity correlations with related alkaloids. Bioorg. Med. Chem. 2005, 13, 443-448. [CrossRef]

88. Ahn, J.H.; Kim, E.S.; Lee, C.; Kim, S.; Cho, S.-H.; Hwang, B.Y.; Lee, M.K. Chemical constituents from Nelumbo nucifera leaves and their anti-obesity effects. Bioorg. Med. Chem. Lett. 2013, 23, 3604-3608. [CrossRef] [PubMed]

89. Yan, M.-Z.; Chang, Q.; Zhong, Y.; Xiao, B.-X.; Feng, L.; Cao, F.-R.; Pan, R.-L.; Zhang, Z.-S.; Liao, Y.-H.; Liu, X.-M. Lotus leaf alkaloid extract displays sedative-hypnotic and anxiolytic effects through GABAA receptor. J. Agric. Food Chem. 2015, 63, 9277-9285. [CrossRef] [PubMed]

90. Kim, J.-H.; Kang, M.; Cho, C.; Chung, H.-S.; Kang, C.-W.; Parvez, S.; Bae, H. Effects Of Nelumbinis semen on contractile dysfunction in ischemic and reperfused rat heart. Arch. Pharm. Res. 2006, 29, 777-785. [CrossRef] [PubMed]

91. Wang, X.; Cheang, W.S.; Yang, H.; Xiao, L.; Lai, B.; Zhang, M.; Ni, J.; Luo, Z.; Zhang, Z.; Huang, Y.; et al. Nuciferine relaxes rat mesenteric arteries through endothelium-dependent and -independent mechanisms: Nuciferine relaxes rat mesenteric arteries. Br. J. Pharmacol. 2015, 172, 5609-5618. [CrossRef] [PubMed]

92. Zhang, D.-D.; Zhang, J.-G.; Wu, X.; Liu, Y.; Gu, S.-Y.; Zhu, G.-H.; Wang, Y.-Z.; Liu, G.-L.; Li, X.-Y. nuciferine downregulates per-arnt-sim kinase expression during its alleviation of lipogenesis and inflammation on oleic acid-induced hepatic steatosis in HepG2 Cells. Front. Pharmacol. 2015, 6, 238. [CrossRef]

93. Nakamura, S.; Nakashima, S.; Tanabe, G.; Oda, Y.; Yokota, N.; Fujimoto, K.; Matsumoto, T.; Sakuma, R.; Ohta, T.; Ogawa, K.; et al. Alkaloid constituents from flower buds and leaves of sacred Lotus (Nelumbo nucifera, Nymphaeaceae) with melanogenesis inhibitory activity in B16 Melanoma Cells. Bioorg. Med. Chem. 2013, 21, 779-787. [CrossRef] 
94. Kredy, H.M.; Huang, D.; Xie, B.; He, H.; Yang, E.; Tian, B.; Xiao, D. Flavonols of Lotus (Nelumbo nucifera, Gaertn.) seed epicarp and their antioxidant potential. Eur. Food Res. Technol. 2010, 231, 387-394. [CrossRef]

95. Chen, S.; Wu, B.-H.; Fang, J.-B.; Liu, Y.-L.; Zhang, H.-H.; Fang, L.-C.; Guan, L.; Li, S.-H. Analysis of flavonoids from Lotus (Nelumbo nucifera) leaves using high performance liquid chromatography/photodiode array detector tandem electrospray ionization mass spectrometry and an extraction method optimized by orthogonal design. J. Chromatogr. A 2012, 1227, 145-153. [CrossRef]

96. Kato, E.; Inagaki, Y.; Kawabata, J. Higenamine 4'-O- $\beta$-d-glucoside in the lotus plumule induces glucose uptake of L6 cells through $\beta 2$-adrenergic receptor. Bioorg. Med. Chem. 2015, 23, 3317-3321. [CrossRef]

97. Itoh, A.; Saitoh, T.; Tani, K.; Uchigaki, M.; Sugimoto, Y.; Yamada, J.; Nakajima, H.; Ohshiro, H.; Sun, S.; Tanahashi, T. Bisbenzylisoquinoline alkaloids from Nelumbo nucifera. Chem. Pharm. Bull. 2011, 59, 947-951. [CrossRef]

98. Chen, S.; Li, X.; Wu, J.; Li, J.; Xiao, M.; Yang, Y.; Liu, Z.; Cheng, Y. Plumula nelumbinis: A review of traditional uses, phytochemistry, pharmacology, pharmacokinetics and safety. J. Ethnopharmacol. 2021, 266, 113429. [CrossRef] [PubMed]

99. Ghosh, D.K.; Mukherjee, P.K. Natural Medicines: Clinical Efficacy, Safety and Quality; CRC Press: Boca Ration, FL, USA, 2020; ISBN 978-1-315-18785-3.

100. Yen, C.-C.; Tung, C.-W.; Chang, C.-W.; Tsai, C.-C.; Hsu, M.-C.; Wu, Y.-T. Potential risk of higenamine misuse in sports: Evaluation of Lotus Plumule extract products and a human study. Nutrients 2020, 12, 285. [CrossRef] [PubMed]

101. Ahmad, W.; Jantan, I.; Bukhari, S.N.A. Tinospora crispa (L.) Hook. f. \& Thomson: A review of its ethnobotanical, phytochemical, and pharmacological aspects. Front. Pharmacol. 2016, 7, 59. [CrossRef]

102. Li, S.; Long, C.; Liu, F.; Lee, S.; Guo, Q.; Li, R.; Liu, Y. Herbs for medicinal baths among the traditional Yao communities of China J. Ethnopharmacol. 2006, 108, 59-67. [CrossRef] [PubMed]

103. Al-Adhroey, A.H.; Nor, Z.M.; Al-Mekhlafi, H.M.; Mahmud, R. Ethnobotanical study on some Malaysian anti-malarial plants: A Community Based Survey. J. Ethnopharmacol. 2010, 132, 362-364. [CrossRef]

104. Koay, Y.; Koay, F. A review of the secondary metabolites and biological activities of Tinospora crispa (Menispermaceae). Trop. J. Pharm. Res. 2013, 12, 641-649. [CrossRef]

105. Kalsom, Y.U.; Noor, H.M. Flavone O-glycosides from Tinospora crispa. Fitoterapia 1995, 66, 280.

106. Rakib, A.; Ahmed, S.; Islam, M.A.; Haye, A.; Uddin, S.M.N.; Uddin, M.M.N.; Hossain, M.K.; Paul, A.; Emran, T.B. Antipyretic and hepatoprotective potential of Tinospora crispa and investigation of possible lead compounds through in silico approaches. Food Sci. Nutr. 2020, 8, 547-556. [CrossRef]

107. Kongkathip, N.; Dhumma-upakorn, P.; Kongkathip, B.; Chawananoraset, K.; Sangchomkaeo, P.; Hatthakitpanichakul, S. Study on cardiac contractility of cycloeucalenol and cycloeucalenone isolated from Tinospora crispa. J. Ethnopharmacol. 2002, 83, 95-99. [CrossRef]

108. Choudhary, M.I.; Ismail, M.; Ali, Z.; Shaari, K.; Lajis, N.H. Atta-ur-Rahman, null Alkaloidal Constituents of Tinospora crispa. Nat. Prod. Commun. 2010, 5, 1747-1750.

109. Yusoff, M.; Hamid, H.; Houghton, P. Anticholinesterase inhibitory activity of quaternary alkaloids from Tinospora crispa. Molecules 2014, 19, 1201-1211. [CrossRef] [PubMed]

110. Ibahim, M.J.; Wan-Nor, I.W.M.Z.; Ahh, N.; NurulAsyikin, Z.; Sar, S.-N.S.; Ga, F. Anti-proliperative and antioxidant effects of Tinospora crispa (Batawali). Biomed. Res. 2011, 22, 57-62.

111. Cavin, A.; Hostettmann, K.; Dyatmyko, W.; Potterat, O. Antioxidant and lipophilic constituents of Tinospora crispa. Planta Med. 1998, 64, 393-396. [CrossRef] [PubMed]

112. Amom, Z.; Bahari, H.; Isemaail, S.; Ismail, N.A.; Shah, Z.; Arshad, M. Nutritional composition, antioxidant ability and flavonoid content of Tinospora crispa stem. Adv. Nat. Appl. Sci. 2009, 3, 88-94.

113. Ounjaijean, S.; Chachiyo, S.; Somsak, V. Hypoglycemia induced by plasmodium berghei infection is prevented by treatment with Tinospora crispa stem extract. Parasitol. Int. 2019, 68, 57-59. [CrossRef]

114. Lam, S.-H.; Ruan, C.-T.; Hsieh, P.-H.; Su, M.-J.; Lee, S.-S. Hypoglycemic diterpenoids from Tinospora crispa. J. Nat. Prod. 2012, 75, 153-159. [CrossRef]

115. Ruan, C.-T.; Lam, S.-H.; Lee, S.-S.; Su, M.-J. Hypoglycemic action of borapetoside A from the plant Tinospora crispa in mice. Phytomedicine 2013, 20, 667-675. [CrossRef]

116. Hao, D.C.; Gu, X.-J.; Xiao, P.G. Chemical and biological studies of Aconitum pharmaceutical resources. In Medicinal Plants; Elsevier: Amsterdam, The Netherlands, 2015; ISBN 978-0-08-100085-4.

117. Fu, M.; Wu, M.; Qiao, Y.; Wang, Z. Toxicological mechanisms of Aconitum alkaloids. Pharmazie 2006, 61, 735-741.

118. Tai, C.-J.; El-Shazly, M.; Wu, T.-Y.; Lee, K.-T.; Csupor, D.; Hohmann, J.; Chang, F.-R.; Wu, Y.-C. Clinical aspects of Aconitum preparations. Planta Med. 2015, 81, 1017-1028. [CrossRef] [PubMed]

119. Liu, S.; Li, F.; Li, Y.; Li, W.; Xu, J.; Du, H. A Review of traditional and current methods used to potentially reduce toxicity of Aconitum roots in traditional Chinese Medicine. J. Ethnopharmacol. 2017, 207, 237-250. [CrossRef]

120. Tong, P.; Wu, C.; Wang, X.; Hu, H.; Jin, H.; Li, C.; Zhu, Y.; Shan, L.; Xiao, L. Development and assessment of a completedetoxication strategy for Fuzi (lateral root of Aconitum carmichaeli) and Its application in rheumatoid arthritis therapy. $J$. Ethnopharmacol. 2013, 146, 562-571. [CrossRef] [PubMed]

121. Mi, L.; Li, Y.-C.; Sun, M.-R.; Zhang, P.-L.; Li, Y.; Yang, H. A Systematic review of pharmacological activities, toxicological mechanisms and pharmacokinetic studies on Aconitum alkaloids. Chin. J. Nat. Med. 2021, 19, 505-520. [CrossRef] 
122. Zhou, G.; Tang, L.; Zhou, X.; Wang, T.; Kou, Z.; Wang, Z. A review on phytochemistry and pharmacological activities of the processed lateral root of Aconitum carmichaelii Debeaux. J. Ethnopharmacol. 2015, 160, 173-193. [CrossRef]

123. Peng, C.-Y.; Liu, J.-Q.; Zhang, R.; Shu, J.-C. A New alkaloid from the fruit of Nandina domestica Thunb. Nat. Prod. Res. 2014, 28, 1159-1164. [CrossRef]

124. Ikuta, A.; Itokawa, H. Alkaloids of tissue cultures of Nandina domestica. Phytochemistry 1988, 27, 2143-2145. [CrossRef]

125. Qin, J.; Zhang, S.-Y.; Zhang, Y.-B.; Chen, L.-F.; Chen, N.-H.; Wu, Z.-N.; Luo, D.; Wang, G.-C.; Li, Y.-L. Two new isoquinoline alkaloids from the seeds of Nandina domestica. Nat. Prod. Res. 2021, 35, 3254-3260. [CrossRef]

126. Kodai, T.; Horiuchi, Y.; Nishioka, Y.; Noda, N. Novel cycloartane-type triterpenoid from the fruits of Nandina domestica. J. Nat. Med. 2010, 64, 216-218. [CrossRef]

127. Tsukiyama, M.; Akaishi, T.; Ueki, T.; Okumura, H.; Abe, K. The Extract from Nandina domestica THUNBERG inhibits histamineand serotonin-induced contraction in isolated guinea pig trachea. Biol. Pharm. Bull. 2007, 30, 2063-2068. [CrossRef]

128. Ueki, T.; Akaishi, T.; Okumura, H.; Abe, K. Extract from Nandina domestica inhibits lipopolysaccharide-induced cyclooxygenase-2 expression in human pulmonary epithelial A549 cells. Biol. Pharm. Bull. 2012, 35, 1041-1047. [CrossRef]

129. Tian, L.-W.; Lv, J.-J.; Liu, Y.; Song, L.-Y.; Hou, L.-B.; Zhong, C.; Xie, Y. A New dimeric stilbene from the lianas of Gnetum Parvifolium. Nat. Prod. Res. 2017, 31, 1495-1500. [CrossRef]

130. Deng, N.; Chang, E.; Li, M.; Ji, J.; Yao, X.; Bartish, I.V.; Liu, J.; Ma, J.; Chen, L.; Jiang, Z.; et al. transcriptome characterization of Gnetum Parvifolium reveals candidate genes involved in important secondary metabolic pathways of flavonoids and stilbenoids. Front. Plant Sci. 2016, 7, 174. [CrossRef] [PubMed]

131. Tang, X.; Tang, P.; Ma, L.; Liu, L. Screening and evaluation of xanthine oxidase inhibitors from Gnetum parvifolium in China Molecules 2019, 24, 2671. [CrossRef]

132. Lee, J.Y.; Moon, S.S.; Hwang, B.K. Isolation and antifungal activity of kakuol, a propiophenone derivative from Asarum sieboldii rhizome. Pest Manag. Sci. 2005, 61, 821-825. [CrossRef]

133. Wagner, H.; Bauer, R.; Melchart, D.; Xiao, P.-G.; Staudinger, A. Radix et Rhizoma Asari-Xixin. In Chromatographic Fingerprint Analysis of Herbal Medicines; Wagner, H., Bauer, R., Melchart, D., Xiao, P.-G., Staudinger, A., Eds.; Springer: Vienna, Austria, 2011; ISBN 978-3-7091-0762-1.

134. Quang, T.H.; Ngan, N.T.T.; Minh, C.V.; Kiem, P.V.; Tai, B.H.; Thao, N.P.; Song, S.B.; Kim, Y.H. Anti-Inflammatory and PPAR transactivational effects of secondary metabolites from the roots of Asarum sieboldii. Bioorg. Med. Chem. Lett. 2012, 22, 2527-2533. [CrossRef]

135. Yu, H.-H.; Seo, S.-J.; Hur, J.-M.; Lee, H.-S.; Lee, Y.-E.; You, Y.-O. Asarum sieboldii extracts attenuate growth, acid production, adhesion, and water-insoluble glucan synthesis of Streptococcus mutans. J. Med. Food 2006, 9, 505-509. [CrossRef]

136. Jeong, M.; Kim, H.; Lee, J.; Choi, J.-H.; Jang, D. (-)-Asarinin from the roots of Asarum sieboldii induces apoptotic cell death via caspase activation in human ovarian cancer cells. Molecules 2018, 23, 1849. [CrossRef]

137. Kim, H.-M.; Moon, Y.-S. Asiasari radix inhibits Immunoglobulin E Production on experimental models in vitro and in vivo. Immunopharmacol. Immunotoxicol. 1999, 21, 469-481. [CrossRef]

138. Hashimoto, K.; Yanagisawa, T.; Okui, Y.; Ikeya, Y.; Maruno, M.; Fujita, T. Studies on anti-allergic components in the roots of Asiasarum sieboldi. Planta Med. 1994, 60, 124-127. [CrossRef]

139. Jang, S.; Park, S.H.; Kim, H.K. Simultaneous determination of 6 antiallergic components in Asarum sieboldii using highperformance liquid chromatography. Nat. Prod. Commun. 2020, 15, 1-10. [CrossRef]

140. Li, Y.-L.; Tian, M.; Yu, J.; Shang, M.-Y.; Cai, S.-Q. Studies on morphology and aristolochic acid analogue constituents of Asarum campaniflorum and a comparison with two official species of Asari radix et rhizoma. J. Nat. Med. 2010, 64, 442-451. [CrossRef]

141. Kosuge, T.; Yokota, M.; Nukaya, H.; Gotoh, Y.; Nagasawa, M. Studies on antitussive principles of Asiasari radix. Chem. Pharm. Bull. 1978, 26, 2284-2285. [CrossRef]

142. Han, Y.; Kim, S.-J. Memory enhancing actions of asiasari radix extracts via activation of insulin receptor and extracellular signal regulated kinase (ERK) I/II in rat hippocampus. Brain Res. 2003, 974, 193-201. [CrossRef]

143. Gan, W.; Huang, Q.; Wang, M.; Wang, J.; Hui, Y.; Zhao, K.; Huang, N.; Liao, T. A randomized controlled trial study protocol of modified Mahuang-Fuzi-Xixin decoction in the treatment of patients with mild bronchial asthma during acute exacerbation. Medicine 2020, 99, e21858. [CrossRef]

144. Girard, H.; Court, M.H.; Bernard, O.; Fortier, L.-C.; Villeneuve, L.; Hao, Q.; Greenblatt, D.J.; von Moltke, L.L.; Perussed, L.; Guillemette, C. Identification of common polymorphisms in the promoter of the UGT1A9 gene: Evidence That UGT1A9 protein and activity levels are strongly genetically controlled in the liver. Pharmacogenetics 2004, 14, 501-515. [CrossRef] 